\title{
Evaluation of prevalence's of pfdhfr and pfdhps mutations in Angola
}

Filomeno Fortes ${ }^{1,3}$, Rafael Dimbu1 ${ }^{1,3}$, Paula Figueiredo ${ }^{2,3}$, Zoraima Neto ${ }^{2,3}$, Virgílio E do Rosário 2,3 , Dinora Lopes ${ }^{2,3^{*}}$

\begin{abstract}
Background: Malaria is the major cause of morbidity and mortality in Angola. The most vulnerable groups to Plasmodium falciparum infection are pregnant women and children under five years of age. The use of an intermittent preventive treatment (IPT) with sulphadoxine/pyrimethamine (SP) in pregnant women was introduced in Angola in 2006 by the National Malaria Control Programme, and currently this strategy has been considered to be used for children malaria control. Considering the previous wide use of SP combination in Angola, together to the reported cases of SP treatment failure it is crucial the evaluation of the prevalence of five mutations in pfdhfr and pfdhps genes associated to $P$. falciparum resistance to SP before the introduction of S/P IPT in children.
\end{abstract}

Methods: The study was conducted in five provinces, with different transmission intensities: Huambo, Cabinda, Uíge, Kwanza Norte, and Malanje. The detection of the mutations in pfdhfr and pfdhps genes was carried out in 452 P. falciparum blood samples by PCR RFLP.

Results: For pfdhfr gene, $90,3 \%$ of the samples carried the mutation 511 , with $7.5 \%$ of mixed infections; $51 \%$ carried wild type allele $59 \mathbf{C}$, with $29.2 \%$ mixed infections and; $99.1 \%$ of isolates harboured the mutant allele $108 \mathbf{N}$. Concerning, pfdhps gene, $83,1 \%$ were mutant type $437 \mathbf{G}$ with $11 \%$ mixed infections, while $87 \%$ of the studied isolates were wild type for codon 540.

Discussion: This is the first representative epidemiological study of the whole Angola country on the prevalence of the genotypes associated with SP chemoresistance. A high frequency of individual mutations in both genes (51I and $108 \mathbf{N}$ in pfdhfr, and 437G in pfdhps) was found, besides a low prevalence of the quintuple mutation.

Conclusion: The data showed that the implementation IPT using SP in children needs to be reviewed.

\section{Background}

According to the Angolan National Malaria Control Programme (NMCP), malaria is the major cause of morbidity and mortality in Angola, with four million clinical cases and 20 thousand deaths reported in 2005, accounting for $35 \%$ of the overall mortality in children under five years old and 25\% of the maternal deaths [1-3]. Malaria is endemic throughout the Angolan territory, Plasmodium falciparum being the predominant species [4]. Due to the high prevalence of $P$. falciparum strains resistant to chloroquine [5-8], therapeutic regimens for treatment of uncomplicated $P$. falciparum infection were changed in 2006 [9] and, currently, the first-line treatment for uncomplicated malaria is Coartem ${ }^{\circledR}$ (artemether-

\footnotetext{
* Correspondence: dferreira@ihmt.unl.pt

¿UEl Malária/Centro de Malária e Doenças Tropicais - LA/IHMT/Universidade

Nova de Lisboa, Rua da Junqueira, 100, 1349-008, Lisboa, Portugal

Full list of author information is available at the end of the article
}

lumefantrine) followed by the amodiaquine-artesunate alternative therapy.

Additionally, in all Angolan endemic areas the strategy to protect mothers during their pregnancy includes the use of an intermittent preventive treatment (IPT) $[10,11]$. This intervention has been introduced in Angola since 2006, using sulphadoxine/pyrimethamine (SP) at the second trimester of pregnancy.

In other African countries, SP - ITP has been also introduced in children as a control measure to reduce malaria morbidity and mortality in this most vulnerable population [12] and has been evaluated in a number of clinical trials in these countries, with success [12-17]. Thus, Angolan NMCP intends in the near future to introduce this control measure in Angola. However, due to the wide use of SP combination in this country together to reported cases of SP treatment failure, it was decided to obtain further information about SP resistance

\section{Biomed Central}

(C) 2011 Fortes et al; licensee BioMed Central Ltd. This is an Open Access article distributed under the terms of the Creative Commons Attribution License (http://creativecommons.org/licenses/by/2.0), which permits unrestricted use, distribution, and reproduction in any medium, provided the original work is properly cited. 
in Angola, during a surveillance study carried out in 2007, before the introduction of such a control measure.

It is well known that mutations at the dihydropteroate synthase $(p f d h p s)$ and dihydrofolate reductase ( $p f d h f r)$ genes are associated with resistance of $P$. falciparum to SP, respectively [18-21]. In pfdhfr, point mutations at positions $51,59,108$, and 164 are associated with pyrimethamine resistance [22,23]. Similarly, mutations in codons 437 (437G) and 540 (540E) of pfdhps are associated with resistance to sulphadoxine [24-29].

Thus, to determine the polymorphism of pfdhps and pfdhfr genes, infected blood samples were collected in different representative endemic regions of the whole country (Uíge, Kwanza Norte, Malanje, Cabinda and Huambo) and the prevalence of five mutations of the pfdhfr (N51I, C59R and S108N) and pfdhps (A437G and $\mathrm{K} 540 \mathrm{E})$ genes was investigated.

\section{Methods}

\section{Sample collection and DNA extraction}

The blood samples used for this study were collected originally as part of malaria surveillance activities of NMCP. Community-based surveys were conducted in five areas with different transmission intensity: Huambo, Cabinda, Uíge, Kwanza Norte, and Malanje (Figure 1). These samples were collected from asymptomatic children under five years of age, at time of blood collection. Each sample consisted of $200 \mu \mathrm{l}$ of finger-prick blood spotted on filter papers, dried and stored at room temperature until parasite DNA extraction.

Parent's informed consent was obtained before inclusion in the study, which was reviewed and approved by the Ethical Committee from the Ministry of Health of Angola. DNA was extracted from blood spotted on filter paper, using phenol-chloroform method as described elsewhere [30].

\section{Analysis of mutations}

Polymorphisms on the codons 51, 59, 108 in pfdhfr and 437, 540 in pfdhps were assessed by PCR RFLP after amplification of DNA fragments by nested-PCR. The PCR and enzymes restrictions reactions were carried out under the conditions already described [31,32]. PCR amplicons and digested fragments were separated on $2 \%$ or $3 \%$ agarose gels stained with ethidium bromide and visualized under UV.

\section{Results}

From one thousand and twelve samples collected in five provinces from children that did not exhibit malaria symptoms at the time of blood collection, 452 P. falciparum PCR positive samples were analysed in

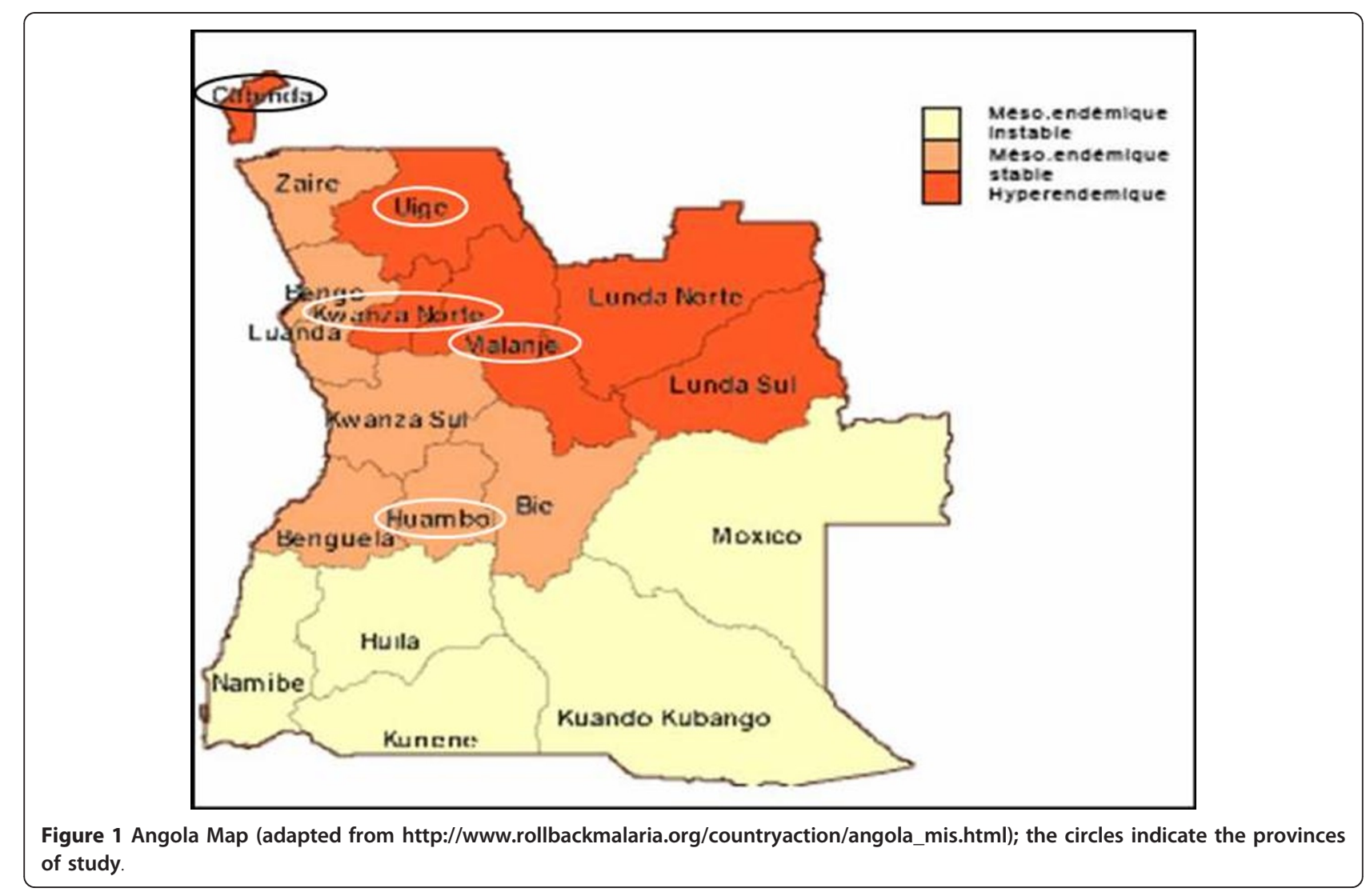


this study: 208 (46\%) were collected in Malanje, 96 (21\%) in Kwanza Norte, 71 (16\%) in Cabinda, 54 (12\%) in Uíge and $23(5 \%)$ in Huambo provinces.

For $p f d h f r$ gene, all 452 samples were successfully characterized by PCR-RFLP for 51, 423 and 59 codons and 430 samples for codon 108. Regarding pfdhps gene, 438 samples were characterized for codon 437 and 448 samples for codon 540. The analysis of pfdhfr showed that $90,3 \%$ (408 out 452 ) of the isolates carried the mutant allele $51 \mathbf{I}$, while $7,5 \%$ (34 out 452 ) carried a mixed infection ( $\mathbf{N}$ and $\mathbf{I}$ ); for 59 codon $51 \%$ (213 out 423) were wild type (C59), 29,2\% (122 out 423) were mixed infections ( $\mathbf{C}$ and $\mathbf{R}$ ) and $19,9 \%$ (83 out 423 ) carried the mutant allele 59R. Concerning the pfdhfr gene codon $108,99,1 \%$ (426 out 430) of isolates harbored the mutant allele (N). For pfdhps 83,1\% (364 out 438) were mutant type $(437 \mathbf{G}), 11 \%$ (48 out 438 ) were mixed populations and $87 \%$ (390 out 448 ) of studied isolates were wild type for codon 540 (K) (Table 1).

A mixture of infections with wild-type and mutant alleles was also observed. These mixed infections were seen for pfdhfr gene in positions 51 (34/452), 59 (122/ 416) and 108 (1/430), and in pfdhps gene in positions $437(45 / 438)$ and $540(29 / 441)$. All mixed infections were excluded from subsequent analysis. Therefore, successful characterization of all five molecular markers was obtained only in 241 samples out of a total of 452 .

Only 25\% (72) of the 400 isolates which were successfully characterized for the studied pfdhfr codons harboured the triple pfdhfr 51-59-108 mutations and one isolate carried the combination of three wild type codons. The more frequent $p f d h f r$ genotype was ICN, which was found in 200 isolates (Table 2). Regarding the pfdhps genotype GK, double mutation (437 and 540 codons) showed the highest frequency (91,1\%). 225 isolates harboured mutations on position 108 of $p f d h f r$ gene and 437 of pfdhps gene that were reported as the initial mutations for pyrimethamine and sulphadoxine resistance, respectively [23-36].

In $p f d h f r$ gene, five mutant genotypes, NCN, NRN, ICN, IRN and NCS (amino acids at positions 51, 59 and 108) were found confirming the major diversity of this gene (Table 2). Among the studied isolates, 74\% were double mutants (ICN or NRN), most of them being type ICN, and the triple mutant IRN was detected in $25 \%$ of the samples. Only one isolate was a single mutant (ICS). In pfdhps, three allele combinations GK, GE and AK (amino acids at positions 437 and 540) were detected nearly $3 \%$ being the double mutant GE and $91 \%$ of the isolates were $\mathbf{G K}$ and $6 \%$ were wild-type (AK). Considering the two studied genes, 12 different genotype combinations were found: NRN GK, ICN GK, IRN GK, IRN GE, ICN AK, IRN AK, ICN GE, NCN AK, NRN AK, ICS GK, NCN GK and NCS GK (51, 59 and 108 for pfdhfr gene and 437 and 540 for $p f d h p s$ gene). From a total of 241 isolates, 63\% were ICN GK, $25 \%$ IRN GK, 3,7\% were ICN AK, ICN GE. NRN GK and IRN AK were detected with same frequency of the $1,7 \%, 1,2 \%$

Table 1 Prevalence of mutations conferring resistance to SP in $P$. falciparum isolates from Angola

\begin{tabular}{|c|c|c|c|c|c|c|}
\hline \multicolumn{7}{|c|}{ Prevalence of mutations in pfdhfr and pfdhps genes (\%) } \\
\hline \multirow{3}{*}{ Province } & \multirow[b]{3}{*}{ Alleles } & \multicolumn{3}{|c|}{ pfdhfr } & \multicolumn{2}{|c|}{ pfdhps } \\
\hline & & 51 & 59 & 108 & 437 & 540 \\
\hline & & n (\%) & n (\%) & n (\%) & n (\%) & n (\%) \\
\hline & wild type & $0(0)$ & $16(27,6)$ & $0(0)$ & $8(12,1)$ & $55(83,3)$ \\
\hline \multirow[t]{3}{*}{ Cabinda } & mutant & $70(98,6)$ & $28(48,3)$ & $64(100)$ & $57(86,4)$ & $3(4,5)$ \\
\hline & mix infection & $1(1,4)$ & $14(24,1)$ & $0(0)$ & $1(1,5)$ & $8(12,1)$ \\
\hline & wild type & $1(1,85)$ & $19(35,8)$ & $0(0)$ & $0(0)$ & $53(98,1)$ \\
\hline \multirow[t]{3}{*}{ Uige } & mutant & $52(96,3)$ & $15(28,3)$ & $50(100)$ & $52(96,3)$ & $1(1,9)$ \\
\hline & mix infection & $1(1,85)$ & $19(35,8)$ & $0(0)$ & $2(3,7)$ & $0(0)$ \\
\hline & wild type & $2(2,1)$ & $46(49,5)$ & $0(0)$ & $0(0)$ & $92(95,8)$ \\
\hline \multirow[t]{3}{*}{ Kwanza Norte } & mutant & $91(94,8)$ & $25(26,9)$ & $92(100)$ & $93(96,9)$ & $2(2,1)$ \\
\hline & mix infection & $3(3,1)$ & $22(23,7)$ & $0(0)$ & $3(3,1)$ & $2(2,1)$ \\
\hline & wild type & $7(3,4)$ & $127(62,6)$ & $3(1,5)$ & $16(7,7)$ & $189(90,9)$ \\
\hline \multirow[t]{3}{*}{ Malanje } & mutant & $173(83,2)$ & $12(5,9)$ & $199(98)$ & $156(75)$ & $5(2,4)$ \\
\hline & mix infection & $28(13,5)$ & $64(31,5)$ & $1(0,5)$ & $34(16,3)$ & $13(6,3)$ \\
\hline & wild type & $0(0)$ & $5(45,5)$ & $0(0)$ & $2(12,5)$ & $11(61,1)$ \\
\hline \multirow[t]{3}{*}{ Huambo } & mutant & $22(95,7)$ & $3(27,3)$ & $21(100)$ & $6(37,5)$ & $1(5,6)$ \\
\hline & mix infection & $1(4,4)$ & $3(27,3)$ & $0(0)$ & $8(50)$ & $6(33,3)$ \\
\hline & wild type & $10(2,2)$ & $213(51,0)$ & $3(0,7)$ & $26(5,9)$ & $390(87,1)$ \\
\hline \multirow[t]{2}{*}{ Total } & mutant & $408(90,3)$ & $83(19,9)$ & $426(99,1)$ & $364(83,1)$ & $29(6,5)$ \\
\hline & mix infection & $34(7,5)$ & $122(29,2)$ & $1(0,2)$ & $48(11,0)$ & $29(6,5)$ \\
\hline
\end{tabular}


Table 2 Prevalence of haplotypes in P. falciparum isolates from Angola

\begin{tabular}{|c|c|c|c|c|c|c|c|c|c|c|c|c|c|}
\hline & \multirow[t]{2}{*}{ Genotypes } & \multicolumn{2}{|c|}{ Cabinda } & \multicolumn{2}{|c|}{ Uige } & \multicolumn{2}{|c|}{ Kwanza Norte } & \multicolumn{2}{|c|}{ Malanje } & \multicolumn{2}{|c|}{ Huambo } & \multicolumn{2}{|c|}{ Total } \\
\hline & & $\mathrm{n}$ & (\%) & $\mathrm{n}$ & $(\%)$ & $\mathrm{n}$ & $(\%)$ & $\mathbf{n}$ & $(\%)$ & $\mathbf{n}$ & $(\%)$ & $\mathrm{n}$ & (\%) \\
\hline & 5159108 & & & & & & & & & & & & \\
\hline & IRN & 28 & 63,6 & 13 & 40,6 & 22 & 32,4 & 5 & 3,9 & 1 & 16,7 & 69 & 24,8 \\
\hline & ICN & 16 & 36,4 & 18 & 56,3 & 44 & 64,7 & 117 & 91,4 & 5 & 83,3 & 200 & 71,9 \\
\hline \multirow[t]{6}{*}{ pfdhfr } & ICS & & 0,0 & & 0,0 & & 0,0 & 1 & 0,8 & & 0,0 & 1 & 0,4 \\
\hline & $\mathrm{NCN}$ & & 0,0 & & 0,0 & & 0,0 & 2 & 1,6 & & 0,0 & 2 & 0,7 \\
\hline & NRN & & 0,0 & 1 & 3,1 & 2 & 2,9 & 3 & 2,3 & & 0,0 & 6 & 2,2 \\
\hline & $\mathrm{n}$ & 44 & & 32 & & 68 & & 128 & & 6 & & 278 & \\
\hline & 437540 & & & & & & & & & & & & \\
\hline & GK & 50 & 87,7 & 51 & 98,1 & 89 & 94,7 & 144 & 89,4 & 5 & 62,5 & 339 & 91,1 \\
\hline \multirow[t]{9}{*}{ pfdhps } & GE & 3 & 5,3 & 1 & 1,9 & 2 & 2,1 & 5 & 3,1 & 1 & 12,5 & 12 & 3,2 \\
\hline & AK & 4 & 7,0 & 0 & 0,0 & 3 & 3,2 & 12 & 7,5 & 2 & 25,0 & 21 & 5,6 \\
\hline & $\mathrm{n}$ & 57 & & 52 & & 94 & & 161 & & 8 & & 372 & \\
\hline & 5159 108/437 540 & & & & & & & & & & & & \\
\hline & ICN/GK & 10 & 27,8 & 17 & 54,8 & 41 & 60,3 & 83 & 81,4 & 1 & 25,0 & 152 & 63,1 \\
\hline & IRN/GK & 22 & 61,1 & 14 & 45,2 & 20 & 29,4 & 4 & 3,9 & 1 & 25,0 & 61 & 25,3 \\
\hline & IRN/AK & 2 & 5,6 & & 0,0 & 2 & 2,9 & & 0,0 & & 0,0 & 4 & 1,7 \\
\hline & ICN/AK & & 0,0 & & 0,0 & 1 & 1,5 & 6 & 5,9 & 2 & 50,0 & 9 & 3,7 \\
\hline & NRN/GK & & 0,0 & & 0,0 & 2 & 2,9 & 1 & 1,0 & & 0,0 & 3 & 1,2 \\
\hline \multirow[t]{8}{*}{ pfdhfr/pfdhps } & ICN/GE & 1 & 2,8 & & 0,0 & 2 & 2,9 & & 0,0 & & 0,0 & 3 & 1,2 \\
\hline & ICS/GK & & 0,0 & & 0,0 & & 0,0 & 1 & 1,0 & & 0,0 & 1 & 0,4 \\
\hline & ICN/GE & & 0,0 & & 0,0 & & 0,0 & 4 & 3,9 & & 0,0 & 4 & 1,7 \\
\hline & NCN/GK & & 0,0 & & 0,0 & & 0,0 & 1 & 1,0 & & 0,0 & 1 & 0,4 \\
\hline & NRN/AK & & 0,0 & & 0,0 & & 0,0 & 1 & 1,0 & & 0,0 & 1 & 0,4 \\
\hline & NCN/AK & & 0,0 & & 0,0 & & 0,0 & 1 & 1,0 & & 0,0 & 1 & 0,4 \\
\hline & IRN/GE & 1 & 2,8 & & 0,0 & & 0,0 & & 0,0 & & 0,0 & 1 & 0,4 \\
\hline & $\mathrm{n}$ & 36 & & 31 & & 68 & & 102 & & 4 & & 241 & \\
\hline
\end{tabular}

were NRN GK and ICN GE, all other combinations were found with a very low frequency (Table 2).

In a comparison evaluation between provinces, the same pattern was found except for Cabinda, where the most frequent genotype was IRN (Tables 1 and 2). This province is geographically separated from the rest of the country.

\section{Discussion}

The monitoring of SP resistance is relevant in order to guide national malaria treatment policies before introduction of SP as IPT in children at Angola. In this light, this study was designed to assess the pfdhfr and pfdhps mutations associated with SP chemoresistance. For this purpose, the mutations at pfdhfr (N51I, C59R and S108N) and pfdhps (A437G and K540E) genes, considered predictive of SP treatment failure [25-27], were assessed in five provinces of Angola. Four of them Uíge, Kwanza Norte, Malanje and Cabinda - are hyperendemic areas, whereas Huambo, is a mesoendemic stable. It this way, it was observed the presence of the mutations 51I and 59R jointly with $108 \mathbf{N}$, which enhances the level of resistance to pyrimethamine when compared with single mutation in codon 108 [35-37]. Similarly, mutations in 437 (437G) and 540 (540E) pfdhps codons are associated with resistance to sulphadoxine [24-29]. In pfdhfr gene, the mutation at position 108 (S108N), which is believed to be the initial mutation causing pyrimethamine resistance, was observed in almost all isolates successfully characterized for this codon (426/430) (Table 1). In pfdhps gene, among the 438 characterized isolates, 364 presented the mutant allele at position 437 , which has been reported as the initial mutation for sulphadoxine resistance in many endemic regions.

From 430 P. falciparum isolates characterized in this study, 99,1\% carried the pfdhfr $108 \mathbf{N}$ mutation. The results also showed that $27 \%$ of $P$. falciparum isolates presented double mutations at codons 59 and 108, indicating the development of resistance against antifolates in Angola. Another double mutant (51I 108N) was observed in 96,7\% of Angolan P. falciparum isolates; these results were consistent with the results obtained in a similar study carried out at Uíge province in 2009 [38].

A $25 \%$ of $p f d h f r$ triple mutant prevalence (51I/59R/ $108 \mathrm{~N}$ ) was also noticed. The prevalence of these 
mutations in association with high prevalence of mutation at position $437 \mathbf{G}$ in pfdhps $(83,1 \%)$ may indicate that these $P$. falciparum parasite populations have the potential to evolve into $p f d h f r / p f d h p s$ quintuple mutant in the near future, a mutant that is considered a molecular marker of SP treatment failure [25-27].

In addition, the simultaneously presence of $59 \mathbf{R} p f d h f r$ and $540 \mathrm{E}$ pfdhps variants is considered predictive of the presence of quintuple mutant (pfdhfr 51I, 59R, 108N, pfdhps 437G, 540E) [25-40]. In fact, despite high frequencies of mutations in this report, only one isolate was found harbouring the quintuple mutant associated with high level of resistance to SP. This finding is in accordance with the results obtained in other similar studies carried out in Angola, Republic of Congo and Gabon [31,28,29].

The predominant $p f d h f r$ haplotype in the present work was $51 \mathbf{I} 59 \mathbf{C} 108 \mathbf{N}(71,9 \%)$, corroborating the results reported with Brazilian samples by Gama and collaborators [41]. The triple mutant 51I59R108N $(24,8 \%)$ was of low prevalence in the examined isolates, similarly to previous data reported in Sri Lanka [42] and Papua New Guinea [43], but different from the isolates from Malaysia [44], Brazil [45] and India [46] where this triple mutant was the predominant haplotype. In Africa, the Republic of Congo [28] and Gabon [29] also shows differences when compared with these Angolan data, except in the province of Cabinda. The differences found between Cabinda isolates and the rest of studied isolates may be due to geographical location of this province and its proximity to the neighboring countries Gabon and Congo and the movement of people between these regions. Most of the P. falciparum isolates $(91,1 \%)$ revealed the haplotype 437G540K for pfdhps gene with low prevalence of mutation at codon $540(3,2 \%)$.

The triple $p f d h f r / p f d h p s$ (59R108N/437G) mutant haplotype was found in $27 \%$ of isolates, the 51 II $108 \mathrm{~N} /$ 437G was the mutant haplotype more prevalent in studied isolates.

The results obtained in the present study are in line with those obtained with Iranian isolates where 51I mutation seems be a good molecular marker for the triple mutant $p f d h f r / p f d h p s$ [47]. By the other hand, theses results seem to be in contrast with the data obtained in a study carried out in Mozambique which claimed that the mutations at codon 59 in pfdhfr and codon 437 in pfdhps were enough to predict SP treatment failure [48], as well as in Burkina Faso [49] where the results showed that pfdhfr 59R is more relevant than the 51I as a marker of SP treatment failure.

Finally, this is the first molecular study carried out in Angola including a large number of samples (452) from five different provinces of the country, and where five mutations of pfdhps and pfdhfr genes, predictive of SP therapeutic failure were screening showing high frequencies of $51 \mathbf{I}, 108 \mathbf{N} p f d h f r$ alleles, and $437 \mathbf{G}$ of pfdhps gene with an almost absence of the quintuple mutation for SP.

\section{Conclusion}

The high frequencies of mutations and haplotypes linked to antimalarial treatment failure (for example the $88 \%$ frequency of isolates carrying pfdhfr 51 II $108 \mathbf{N}$ pfdhps 437G triple mutant allele, critical to SP resistance) herein described, highlight the need to revaluate the strategy of SP introduction as an IPT in children as well as the current use of SP for pregnant women IPT purposes, in Angola.

\section{Acknowledgements}

This study has financial support from PNCM/MINSA. The authors are grateful to the children involved in the study and the staff of PNCM who collaborated in sample collection.

\section{Author details}

${ }^{1}$ Programa Nacional de Controlo da Malária/Ministério da Saúde de Angola, Luanda, Angola. ${ }^{2}$ UEI Malária/Centro de Malária e Doenças Tropicais - LA/ IHMT/Universidade Nova de Lisboa, Rua da Junqueira, 100, 1349-008, Lisboa, Portugal. ${ }^{3}$ Health Progress and Investigation Network of PortugueseSpeaking Countries Community (RIDES/CPLP), Centro de Malária e Doenças Tropicais - LA, Instituto de Higiene e Medicina Tropical, Universidade Nova de Lisboa, Lisboa, Portugal.

\section{Authors' contributions}

FF coordinated sample collection. FF, RD carried out the selection of children and sample collection. RD, ZN and DL carried out DNA extraction and Plasmodium species identification. PF carried out the molecular analyses. FF, VEdR and DL coordinated and designed the study. DL drafted this manuscript. All authors read and approved the final manuscript.

\section{Competing interests}

The authors declare that they have no competing interests.

Received: 9 August 2010 Accepted: 2 February 2011

Published: 2 February 2011

\section{References}

1. World Health Organization/UNICEF: World Malaria Report 2005. 2005 [http://whqlibdoc.who.int/publications/2005/9241593199_eng.pdf]

2. Brabin BJ: An analysis of malaria in pregnancy in Africa. Bull World Health Organ 1983, 61:1005-1016.

3. Nosten F, ter Kuile F, Maelankirri L, Decludt B, White NJ: Malaria during pregnancy in an area of unstable endemicity. Trans $R$ Soc Trop Med Hyg 1991, 85:424-429.

4. World Health Organization: Communicable Disease Toolkit for Angola. 2005 [http://whqlibdoc.who.int/hq/2005/ WHO_CDS_NTD_DCE_2005a_profile.pdf].

5. Kyronseppa H, Lumio J, Ukkonen R, Pettersson T: Chloroquine-resistant malaria from Angola. Lancet 1984, 1:1244.

6. Olsen $\mathrm{W}$, Jensen $\mathrm{T}$, Jorgensen M: Chloroquine-resistant Plasmodium falciparum malaria from Angola. Lancet 1984, 1:1462-463.

7. Lindberg J, Sandberg T, Bjorkholm B, Bjorkman A: Chloroquine and Fansidar resistant malaria acquired in Angola. Lancet 1985, 1:765.

8. Guthmann JP, Ampuero J, Fortes F, van Overmeir C, Gaboulaud V, Tobback S, Dunand J, Saraiva N, Gillet P, Franco J, Denoncin A, van Herp M, Balkan S, Dujardin JC, D'Alessandro U, Legros D: Antimalarial efficacy of chloroquine, amodiaquine, sulfadoxine-pyrimethamine, and the combinations of amodiaquine + artesunate and sulfadoxinepyrimethamine + artesunate in Huambo and Bie provinces, central Angola. Trans R Soc Trop Med Hyg 2005, 99:485-492. 
9. World Health Organization: Global AMD database. AFRO 2005 [http://www. who.int/countries/en/].

10. Nahlen BL: Rolling back malaria in pregnancy. N Engl J Med 2000, 343:651-652.

11. WHO: A strategic Framework for Malaria Prevention and Control during Pregnancy in the Africa Region. 2004 [http://whqlibdoc.who.int/afro/2004/ AFR_MAL_04.01.pdf].

12. Schellenberg DM, Aponte JJ, Kahigwa EA, Mshinda H, Tanner M, Menendez C, Alonso PL: The incidence of clinical malaria detected by active case detection in children in Ifakara, southern Tanzania. Trans $R$ Soc Trop Med Hyg 2003, 97:647-54.

13. Massaga JJ, Kitua AY, Lemnge MM, Akida JA, Malle LN, Rønn AM, Theander TG, Bygbjerg IC: Effect of intermittent treatment with amodiaquine on anaemia and malarial fevers in infants in Tanzania: a randomised placebo-controlled trial. Lancet 2003, 361:1853-1860

14. Chandramohan D, Owusu-Agyei S, Carneiro I, Awine T, Amponsa-Achiano K, Mensah N, Jaffar S, Baiden R, Hodgson A, Binka F, Greenwood B: Cluster randomised trial of intermittent preventive treatment for malaria in infants in area of high, seasonal transmission in Ghana. BMJ 2005, 331:727-33.

15. White NJ: Antimalarial drug resistance. J Clin Invest 2004, 113:1084-92.

16. Macete E, Aide P, Aponte JJ, Sanz S, Mandomando I, Espasa M, Sigauque B, Dobaño C, Mabunda S, DgeDge M, Alonso P, Menendez C: Intermittent preventive treatment for malaria control administered at the time of routine vaccinations in Mozambican infants: a randomized, placebocontrolled trial. J Infect Dis 2006, 194:276-285.

17. Kobbe R, Adjei S, Kreuzberg C, Kreuels B, Thompson B, Thompson PA Marks F, Busch W, Tosun M, Schreiber N, Opoku E, Adjei O, Meyer CG, May J: Malaria incidence and efficacy of intermittent preventive treatment in infants (IPTi). Malar J 2007, 6:163.

18. Wongsrichanalai C, Pickard AL, Wernsdorfer WH, Meshnick SR: Epidemiology of drug-resistant malaria. Lancet Infect Dis 2002, 2:209-218.

19. Le Bras J, Durand R: The mechanisms of resistance to antimalarial drugs in Plasmodium falciparum. Fundam Clin Pharmacol 2003, 17:147-153.

20. Jelinek T, Rønn AM, Lemnge MM, Curtis J, Mhina J, Duraisingh MT, Bygbjerg IC, Warhurst DC: Polymorphisms in the dihydrofolate reductase (DHFR) and dihydropteroate synthetase (DHPS) genes of Plasmodium falciparum and in vivo resistance to sulphadoxine/pyrimethamine in isolates from Tanzania. Trop Med Int Health 1998, 3:605-609.

21. Ngo T, Duraisingh M, Reed M, Hipgrave D, Biggs B, Cowman AF: Analysis of pfcrt, pfmdr1, dhfr, and dhps mutations and drug sensitivities in Plasmodium falciparum isolates from patients in Vietnam before and after treatment with artemisinin. Am J Trop Med Hyg 2003, 68:350-356.

22. Cowman AF, Morry MJ, Biggs BA, Cross GA, Foote SJ: Amino acid changes linked to pyrimethamine resistance in the dihydrofolate reductasethymidylate synthase gene of Plasmodium falciparum. Proc Natl Acad Sci USA 1988, 85:9109-9113.

23. Peterson DS, Walliker D, Wellems TE: Evidence that a point mutation in dihydrofolate reductase-thymidylate synthase confers resistance to pyrimethamine in falciparum malaria. Proc Natl Acad Sci USA 1988, 85:9114-9118.

24. Appawu M, Owusu-Agyei S, Dadzie S, Asoala V, Anto F, Koram K, Rogers W, Nkrumah F, Hoffman SL, Fryauff DJ: Malaria transmission dynamics at a site in northern Ghana proposed for testing malaria vaccines. Trop Med Int Health 2004, 9:164-170.

25. Bwijo B, Kaneko A, Takechi M, Zungu IL, Moriyama Y, Lum JK, Tsukahara T, Mita T, Takahashi N, Bergquist Y, Björkman A, Kobayakawa T: High prevalence of quintuple mutant $\mathrm{dhps} / \mathrm{dhfr}$ genes in Plasmodium falciparum infections seven years after introduction of sulfadoxine and pyrimethamine as first line treatment in Malawi. Acta Trop 2003, 85:363-373.

26. Kublin JG, Dzinjalamala FK, Kamwendo DD, Malkin EM, Cortese JF, Martino LM, Mukadam RA, Rogerson SJ, Lescano AG, Molyneux ME, Winstanley PA, Chimpeni P, Taylor TE, Plowe CV: Molecular markers for failure of sulfadoxine-pyrimethamine and chlorproguanil- dapsone treatment of Plasmodium falciparum malaria. J Infect Dis 2002, 185:380-388.

27. Nzila AM, Mberu EK, Sulo J, Dayo H, Winstanley PA, Sibley CH, Watkins WM: Towards an understanding of the mechanism of pyrimethaminesulfadoxine resistance in Plasmodium falciparum: genotyping of dihydrofolate reductase and dihydropteroate synthase of Kenyan parasites. Antimicrob Agents Chemother 2000, 44:991-996.
28. Nsimba B, Jafari-Guemouri S, Malonga DA, Mouata AM, Kiori J, Louya F, Yocka D, Malanda M, Durand R, Le Brás J: Epidemiology of drug-resistant malaria in Republic of Congo: using molecular evidence for monitoring antimalarial drug resistance combined with assessment of antimalarial drug use. Trop Med Int Health 2005, 10:1030-1037.

29. Aubouy A, Jafari S, Huart V, Migot-Nabias F, Mayombo J, Durand R, Bakary M, Le Bras J, Deloron P: DHFR and DHPS genotypes of Plasmodium falciparum isolates from Gabon correlate with in vitro activity of pyrimethamine and cycloguanil, but not with sulfadoxinepyrimethamine treatment efficacy. J Antimicrob Chemother 2003, 52:43-49.

30. Snounou G, Viriyakosol S, Zhu XP, Jarra W, Pinheiro L, do Rosario VE, Thaithongs S, Brown KN: High sensitivity of detection of human malaria parasites by the use of nested polymerase chain reaction. Mol Biochem Parasitol 1993, 61:315-320.

31. Figueiredo $P$, Benchimol C, Lopes D, Bernardino L, do Rosário VE, Varandas L, Nogueira F: Prevalence of pfmdr1, pfcrt, pfdhfr and pfdhps mutations associated with drug resistance, in Luanda, Angola. Malar J 2008, 7:236.

32. Cravo P, Figueiredo S, Nogueira F, Lopes D, Ferreira ID, Ferreira C, do Rosario VE: High frequency of the genetic polymorphisms associated with sulfadoxine-pyrimethamine resistance, among Plasmodium falciparum isolates from Sao Tome and Principe, West Africa. Ann Trop Med Parasitol 2004, 98:293-296.

33. Mockenhaupt FP, Eggelte TA, Till H, Bienzle U: Plasmodium falciparum pfcrt and pfmdr1 polymorphisms are associated with the pfdhfr N108 pyrimethamine-resistance mutation in isolates from Ghana. Trop Med Int Health 2001, 6:749-755.

34. Durand R, Jafari S, Bouchaud O, Ralaimazava P, Keundjian A, Le Bras J: Plasmodium falciparum: pfcrt and DHFR mutations are associated with failure of chloroquine plus proguanil prophylaxis in travelers. $J$ Infect Dis 2001, 184:1633-1634.

35. Tarnchompoo B, Sirichaiwat C, Phupong W, Intaraudom C, Sirawaraporn W, Kamchonwongpaisan S, Vanichtanankul J, Thebtaranonth Y, Yuthavong Y: Development of 2,4-diaminopyrimidines as antimalarials based on inhibition of the $\mathrm{S} 108 \mathrm{~N}$ and $\mathrm{C} 59 \mathrm{R}+\mathrm{S} 108 \mathrm{~N}$ mutants of dihydrofolate reductase from pyrimethamine resistant Plasmodium falciparum. J Med Chem 2002, 45:1244-1252.

36. Mourier T, Pain A, Barrell B, Griffiths-Jones S: A selenocysteine tRNA and SECIS element in Plasmodium falciparum. RNA 2005, 11:119-122.

37. Sirawaraporn $W$, Sathitkul $T$, Sirawaraporn $R$, Yuthavong $Y$, Santi DV: Antifolate-resistant mutants of Plasmodium falciparum dihydrofolate reductase. Proc Natl Acad Sci USA 1997, 94:1124-1129.

38. Menegon M, Pearce RJ, Inojosa WO, Pisani V, Abel PM, Matondo A, Bisoffi Z, Majori G, Ord R, Warhurst DC, Roper C, Severini C: Monitoring for multidrug-resistant Plasmodium falciparum isolates and analysis of pyrimethamine resistance evolution in Uíge province, Angola. Trop Med Int Health 2009, 14:1251-1257.

39. Mayor A, Serra-Casas E, Sanz S, Aponte JJ, Macete E, Mandomando I, Puyol L, Berzosa P, Dobaño C, Aide P, Sacarlal J, Benito A, Alonso P, Menéndez C: Molecular markers of resistance to sulfadoxinepyrimethamine during intermittent preventive treatment for malaria in Mozambican infants. J Infect Dis 2008, 197:1737-1742.

40. Mbugi EV, Mutayoba BM, Malisa AL, Balthazary ST, Nyambo TB, Mshinda H: Drug resistance to sulphadoxine-pyrimethamine in Plasmodium falciparum malaria in Mlimba, Tanzania. Malar J 2006, 5:94.

41. Gama BE, de Oliveira NK, Zalis MG, de Souza JM, Santos F, DanielRibeiro CT, Ferreira-da-Cruz Mde F: Chloroquine and sulphadoxinepyrimethamine sensitivity of Plasmodium falciparum parasites in a Brazilian endemic area. Malar J 2009, 8:156.

42. Hapuarachchi HC, Dayanath MY, Bandara KB, Abeysundara S, Abeyewickreme W, de Silva NR, Hunt SY, Siblev CH: Point mutations in the dihydrofolate reductase and dihydropteroate synthase genes of Plasmodium falciparum and resistance to sulfadoxine-pyrimethamine in Sri Lanka. Am J Trop Med Hyg 2006, 74:198-204.

43. Mita T, Kaneko A, Hwaihwanje I, Tsukahara T, Takahashi N, Osawa H, Tanabe K, Kobayakawa T, Björkman A: A rapid selection of dhfr mutant allele in Plasmodium falciparum isolates after the introduction of sulfadoxine/pyrimethamine in combination with 4-aminoquinolines in Papua New Guinea. Infect Genet Evol 2006, 6:447-452.

44. Cox-Singh J, Zakaria R, Abdullah MS, Rahman HA, Nagappan S, Singh B: Differences in dihydrofolate reductase but not dihydropteroate synthase 
alleles in Plasmodium falciparum isolates from geographically distinct areas in Malaysia. Am J Trop Med Hyg 2001, 64:28-31.

45. Vasconcelos KF, Plowe CV, Fontes CJ, Kyle D, Wirth DF, Pereira da Silva LH, Zalis MG: Mutations in Plasmodium falciparum dihydrofolate reductase and dihydropteroate synthase of isolates from the Amazon region of Brazil. Mem Inst Oswaldo Cruz 2000, 95:721-728.

46. Das MK, Lumb V, Mittra P, Singh SS, Dash AP, Sharma YD: High chloroquine treatment failure rates and predominance of mutant genotypes associated with chloroquine and antifolate resistance among falciparum malaria patients from the island of Car Nicobar, India. J Antimicrob Chemother 2010, 65:1258-1261.

47. Zakeri S, Gil JP, Bereckzy S, Djadid ND, Bjorkman A: High prevalence of double Plasmodium falciparum dhfr mutations at codons 108 and 59 in the Sistan- Baluchistan Province. Iran J Infect Dis 2003, 187:1828-1829.

48. Alifrangis M, Enosse S, Khalil IF, Tarimo DS, Lemnge MM, Thompson R, Byqbierq IC, Rønn AM: Prediction of Plasmodium falciparum resistance to sulfadoxine/pyrimethamine in vivo by mutations in the dihydrofolate reductase and dihydropteroate synthetase genes: a comparative study between sites of differing endemicity. Am J Trop Med Hyg 2003, 69:601-606.

49. Dokomajilar C, Lankoande ZM, Dorsey G, Zongo I, Ouedraogo JB, Rosenthal PJ: Roles of specific Plasmodium falciparum mutations in resistance to amodiaquine and sulfadoxine-pyrimethamine in Burkina Faso. Am J Trop Med Hyg 2006, 75:162-165.

doi:10.1186/1475-2875-10-22

Cite this article as: Fortes et al:: Evaluation of prevalence's of pfdhfr and pfdhps mutations in Angola. Malaria Journal 2011 10:22

\section{Submit your next manuscript to BioMed Central and take full advantage of:}

- Convenient online submission

- Thorough peer review

- No space constraints or color figure charges

- Immediate publication on acceptance

- Inclusion in PubMed, CAS, Scopus and Google Scholar

- Research which is freely available for redistribution

Submit your manuscript at www.biomedcentral.com/submit 